\title{
REMARKS ON THE THERMOPREFERENDUM OF PALEARCTIC BATS IN THEIR NATURAL HABITATS
}

\author{
by \\ JIŘI GAISLER \\ Institute of Zoology, J. E. Purkyně University, Brno, C.S.S.R.
}

This contribution comprises two remarks of ecological rather than physiological character. Contrary to Herter (1952), Herreid (1967), and Harmata (1969), I did not examine the temperature preference, or thermopreferendum, of bats under experimental conditions but concluded on it only on grounds of temperatures registered in various natural habitats of the bats. Thus, my observations pertain to the thermopreferendum of the resting bats, either inactive or active metabolically.

My first remark concerns the temperatures preferred in winter. Hibernating bats are known to differ as to their requirements for ambient temperatures in their winter quarters, as pointed out, e.g., by Dulić (1958) and by many other authors.

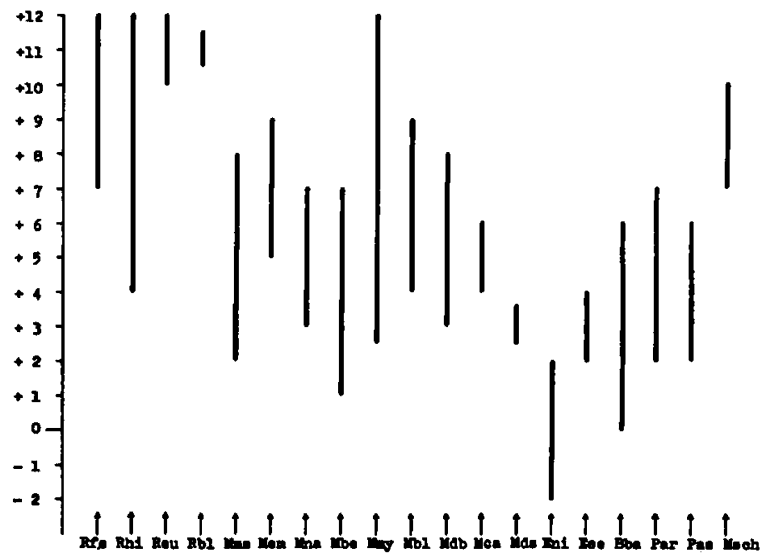

Fig. 1. Temperatures recorded in the underground hibernating quarters of certain bat species (data from Czechoslovakia and Bulgaria). Abbreviations: Rfe - Rhinolophus ferrumequinum, Rhi - $R$. hipposideros, Reu $R$. euryale, Rbl - R. blasii, Mms - Myotis mystacinus, Mem - M. emarginatus, Mna - M. nattereri, Mbe - $M$. bechsteini, Mmy - M. myotis, Mbl - M. blythi, Mdb M. daubentoni, Mca - M. capaccinii, Mds - M.dasycneme, Eni - Eptesicus nilssoni, Ese - E. serotinus, Bba B. barbastellus, Par - Plecotus auritus, Pas - P. austriacus, Msch - Miniopterus schreibersi.
This phenomenon can be illustrated by fig. 1 , showing temperature amplitudes as recorded in close vicinity of hibernating individuals of various species of bats in Czechoslovakia and Bulgaria (the data have been collected during November to March but mostly during February).

Quite accidentally, I was able to observe the effects of a change of temperature in a hibernating quarter irregularly visited (but always in January or February) within a span of twelve years. The cave in question, called "Erichova", is situated on the bottom of the $138 \mathrm{~mm}$ deep Macocha abyss in the Moravian Karst. The cave communicates with the bottom of the abyss by a large entrance, and with an extensive system of stalagmite caves, accessible to the public by a smaller corridor. Normally, this communication is closed by a wooden wall. I examined only the front part of the Erichova Cave, some $50 \mathrm{~m}$ deep, with ambient temperature normally varying between $1^{\circ}$ and $4^{\circ} \mathrm{C}$ in winter. The back part of the cave, situated some $10 \mathrm{~m}$ higher and slanting towards the surface, is consequently substantially warmer than the front part. The neighbouring large caves are also warmer, with ambient temperature $8^{\circ}$ to $9^{\circ} \mathrm{C}$, throughout the year. As indicated in table I, Barbastella barbastellus is the most frequent hibernating species in the Erichova Cave. Table I indicates the numbers of individuals collected; the actual abundance was much higher, being estimated at more than 1000 hibernating individuals in 1963. In February $1966, B$. barbastellus was not found in this locality, nor were bats of the genera Plecotus and Eptesicus. On the other hand, the number of $\mathrm{MyO}$ tis myotis increased conspicuously and, also, there were some individuals of Rhinolophus hipposideros which otherwise frequently hibernate in the adjacent warm caves. It appeared that the wooden wall separating the front part of the Erichova Cave from the extensive adjacent caves had been bro- 
gestive are also the measurements in one of the largest hibernators, the woodchuck (Marmota monax, cf. Lyman, 1958) in which the entrance was accompanied by clear variations in heart rate and metabolism. This widespread distribution of variations during entrance into cold-lethargy suggests that they are common in hibernators, and that they are related to the lowering of the thermoregulatory level from normothermy to lethargy. But the amount of data is too small to establish a regularity in timing of these peaks in rodents similar to the regular timing found in $M$. myotis.

\section{REFERENCES}

Bartholomew, G. A. \& J. W. Hudson, 1960. Aestivation in the mohave ground squirrel. Bull. Mus. comp. Zool. Harvard, 124 : 193-208.

BrücK, K. \& B. WüNNENBERG, 1965. Blockade der chemischen Thermogenese und Auslösung von Muskelzittern durch Adrenolytica und Ganglienblockade beim neugeborenen Meerschweinchen. Pflügers Arch. ges. Physiol., 282 : 376-298.

Heldmaier, G., 1969. Die Thermogenese der Mausohrfledermaus (Myotis myotis) beim Erwachen aus dem Winterschlaf. Z. vergl. Physiol., 63 : 59-84.

一, in preparation. Z. vergl. Physiol. (1970).

Hudson, J. W., 1965. Temperature regulation and torpidity in the pygmy mouse, Baiomys taylori. Physiol. Zool., 38 : $243-253$.

JANSKÝ, L. \& J. HANEK, 1961. Thermogenesis of the bat Myotis myotis Borkh. Physiol. bohemoslov., 10 : 283 $-298$.

Kristoffersson, R. \& A. SoIvio, 1964. Hibernation in the hedgehog (Erinaceus europaeus L.). Changes of respiratory pattern, heart rate and body temperature in response to gradually decreasing or increasing ambient temperature. Ann. Acad. sci. Fenn., (A) (Biol. IV) $82: 1-17$.
Kulzer, E. (1967). Die Herztätigkeit bei lethargischen und winterschlafenden Fledermäusen. Z. vergl. Physiol., 56 : 63-94.

LYMaN, C. P., 1958. Oxygen consumption, body temperature and heart rate of woodchucks entering hibernation. Amer. J. Physiol., 194 : 83-91.

Lyman, C. P. \& R. C. O'BRIEN, 1960. Circulatory changes in the thirteen-lined ground squirrel during the hibernating cycle. Bull. Mus. comp. Zool. Harvard, 124 : $353-372$.

Menaker, M., 1959. Endogenous rhythms of body temperature in hibernating bats. Nature, London, 184 : $1251-1252$.

,- 1961 . The free running period of the bat clock; seasonal variations at low body temperature. J. cell. comp. Physiol., 57 : $81-86$.

PoHL, H., 1961. Temperaturregulation und Tagesperiodik des Stoffwechsels bei Winterschläfern. Z. vergl. Physiol., 45 : 109-153.

STRUMWASSER, F., 1959. Thermoregulatory, brain and behavioural mechanisms during entrance into hibernation in the, squirrel, Citellus beecheyi. Amer. J. Physiol., 196 : 15-22. 